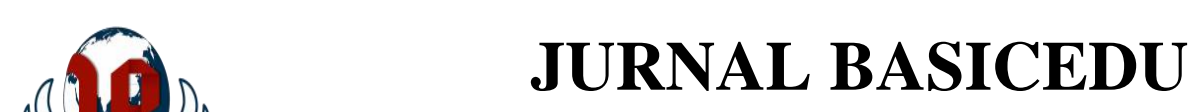

Volume 5 Nomor 2 Tahun 2021 Halaman 1094 - 1103

Research \& Learning in Elementary Education

https://jbasic.org/index.php/basicedu

PAIVERSITAS

\title{
Meta-Analisis Pengaruh Pendekatan Pendidikan Matematika Realistik (PMR) Terhadap Hasil Belajar Siswa Sekolah Dasar
}

\author{
Ripka Yuspin Puspitasari ${ }^{1}{ }^{凶}$, Gamaliel Septian Airlanda $^{2}$ \\ Pendidikan Guru Sekolah Dasar, Univeritas Kristen Satya Wacana, Indonesia ${ }^{1,2}$ \\ E-mail: 292017009@ student.uksw.edu'1 ${ }^{1}$, gamaliel.septian@uksw.edu²
}

\begin{abstract}
Abstrak
Pendekatan pembelajaran yang dapat diterapkan dalam pembelajaran matematika adalah pendekatan pendidikan matematika realistik, karena memiliki kelebihan yaitu lebih memberikan pengertian yang jelas kepada siswa tentang keterkaitan matematika dengan kehidupan sehari-hari dan dalam bimbingan guru siswa dapat menyelesaikan masalah matematikanya. Tujuan dari penelitian ini adalah untuk mengetahui pengaruh Pendekatan Pendidikan Matematika Realistik terhadap Hasil Belajar Matematika Pada Siswa Sekolah Dasar. Jenis penelitian ini adalah meta-analisis. Dari hasil penelusuran diperoleh 20 jurnal ilmiah semua sampel merupakan penelitian eksperimen. Teknik analisis data pada penelitian ini menggunakan metode pembanding untuk menentukan dampak penerapan pendekatan pembelajaran Realistic Mathematics Education (RME). Selanjutnya digunakan uji paired sample t-test untuk melihat rata-rata peningkatan sebelum dan sesudah tindakan kelas, serta untuk mengetahui apakah terdapat perbedaan rata-rata dua kelompok yang saling berpasangan atau berhubungan. Data hasil analisis diperoleh bahwa presentase rata-rata peningkatan hasil belajar siswa dengan pembelajaran menggunakan Pendekatan Pendidikan Matematika Realistik (PMR) dapat meningkatkan hasil belajar kognitif siswa dari yang terendah 13,06\% menjadi tertinggi 99,97\% dan peningkatan rata-rata sebesar 30,34\%. Berdasarkan analisis data maka dapat disimpulkan bahwa pendekatan pembelajaran pendidikan matematika realistik (PMR) memberikan efek yang positif terhadap peningkatan hasil belajar kognitif matematika siswa Sekolah Dasar.
\end{abstract}

Kata Kunci: Pembelajaran Matematika SD, Pendidikan Matematika Realistik, Hasil Belajar Kognitif

\begin{abstract}
The learning approach that can be applied in mathematics learning is a realistic mathematics education approach, because it has the advantage that it provides a clearer understanding of the relationship between mathematics and daily life and in teacher guidance students can solve their mathematics problems. The purpose of this study was to determine the effect of the Realistic Mathematics Education Approach on Mathematics Learning Outcomes in Elementary School Students. This type of research is a meta-analysis. From the search results obtained 20 scientific journals all samples are experimental research. The data analysis technique in this study used a comparative method to determine the impact of implementing the Realistic Mathematics Education (RME) learning approach. Furthermore, the paired sample t-test is used to see the average increase before and after the class action, and to find out whether there is a difference in the average of the two groups that are paired or related. The data from the analysis showed that the average percentage increase in student learning outcomes by learning using the Realistic Mathematics Education Approach (PMR) could improve student cognitive learning outcomes from the lowest $13.06 \%$ to the highest $99.97 \%$ and an average increase of 30 , $34 \%$. Based on data analysis, it can be concluded that the realistic mathematics education learning approach (PMR) has a positive effect on improving the cognitive learning outcomes of elementary school students.
\end{abstract}

Keywords: Elementary Mathematics Learning, Realistic Mathematics Education, Cognitive Learning Outcomes.

Copyright (c) 2021 Ripka Yuspin Puspitasari, Gamaliel Septian Airlanda

Corresponding author :

Email :292017009@student.uksw.edu

DOI : https://doi.org/10.31004/basicedu.v5i2.878

ISSN 2580-3735 (Media Cetak)

ISSN 2580-1147 (Media Online)

Jurnal Basicedu Vol 5 No 2 Tahun 2021

p-ISSN 2580-3735 e-ISSN 2580-1147 
1095 Meta-Analisis Pengaruh Pendekatan Pendidikan Matematika Realistik (PMR) Terhadap hasil Belajar Siswa Sekolah Dasar-Ripka Yuspin Puspitasari, Gamaliel Septian

DOI : https://doi.org/10.31004/basicedu.v5i2.878

\section{PENDAHULUAN}

Pendidikan merupakan salah satu sarana untuk membangun kecerdasan sekaligus kepribadian manusia. Pendidikan juga merupakan kunci utama bagi suatu bangsa untuk menyiapkan masa depan dan sanggup bersaing dengan bangsa lain. Sekolah memiliki peran penting yang sesuai dengan tujuan pendidikan nasional. Pendidikan yang efektif adalah kondisi dimana suatu pendidikan yang dapat memungkinkan siswa untuk dapat belajar dengan mudah, menyenangkan dan dapat tercapai tujuan sesuai dengan yang diharapkan. Seorang pendidik perlu menggali masalah dan potensi siswa, seringkali para pendidik selalu memaksakan kehendaknya dan mengabaikan kebutuhan yang dimiliki siswanya. Padahal yang perlu diperhatikan adalah kebutuhan siswa, bukan memaksakan sesuatu yang tidak disukainya dan membuat siswa kurang nyaman dalam menuntut ilmu. Proses pendidikan yang baik adalah dengan membiarkan anak berpikir kreatif sebab pada dasarnya gaya berpikir tidak bisa diarahkan. Dengan demikian pendidik dituntut untuk meningkatkan keefektifan dalam proses pembelajaran agar pembelajaran tersebut dapat menyenangkan siswa dan berguna. Pembelajaran merupakan salah satu proses pokok dalam pendidikan. Melalui pembelajaran siswa dapat memahami lingkungan sekitar. Siswa mampu melakukan atau mewujudkan tingkah laku tertentu yang merupakan cerminan dari belajarnya. Mengenal berbagai model dalam proses pembelajaran adalah sesuatu yang sangat penting untuk diketahui oleh pendidik. Pentingnya model-model ini tentu merupakan suatu hal yang sangat penting bagi insan pendidikan kita seperti kehilangan arah pembelajaran dan pengajaran akibat terlalu banyak kepentingan yang terjadi di dalamnya.

Pembelajaran merupakan salah satu proses pokok dalam pendidikan. Melalui pembelajaran siswa dapat memahami lingkungan sekitar. Siswa mampu melakukan atau mewujudkan tingkah laku tertentu yang merupakan cerminan dari belajarnya. Mengenal berbagai model dalam proses pembelajaran adalah sesuatu yang sangat penting untuk diketahui oleh pendidik. Pentingnya model-model ini tentu merupakan suatu hal yang sangat penting bagi insan pendidikan kita seperti kehilangan arah pembelajaran dan pengajaran akibat terlalu banyak kepentingan yang terjadi di dalamnya. Pada proses pembelajaran, secara umum anak kurang didorong untuk mengembangkan kemampuan berpikir. Khususnya dalam pembelajaran di dalam kelas, siswa sering diarahkan pada kemampuan cara menggunakan rumus, menghafal rumus, matematika hanya mengerjakan soal, akan tetapi jarang diajarkan untuk bagaimana menganalasis dan menggunakan matematika dalam kehidupan sehari-hari. Akibatnya, apabila siswa diberi soal aplikasi atau soal yang berbeda dengan soal latihannya, maka sering membuat siswa melakukan kesalahan. Dalam proses pembelajaran matematika guru masih mengandalkan metode ceramah yang selalu diterapkan pada Kurikulum Tingkat Satuan Pendidikan (KTSP) dan mengabaikan pembelajaran yang menitikberatkan pada proses. Penggunaan metode pembelajaran yang tidak membiarkan peserta didik berpartisipasi dalam proses pembelajaran mengakibatkan peserta didik cenderung diam dan tidak memerhatikan guru yang sedang menjelaskan, belum ada usaha siswa untuk mencari informasi yang relevan dengan materi yang diajarkan guru. Hal ini mengakibatkan hasil belajar peserta didik menjadi rendah.

Pendekatan pembelajaran dapat diartikan sebagai ide atau prinsep dalam menentukan proses kegiatan belajar-mengajar yang sifatnya masih sangat umum Pendekatan pembelajaran yang dapat diterapkan dalam proses belajar mengajar dalam matematika adalah pendekatan bimbingan menghitung realistik, karena penghampiran ini menyimpan banyak keunggulan yaitu lebih membagikan pengertian yang sangat jelas kepada siswa tentang pelajaran berhitung yang dihubungkan kedalam aktivitas sehari-hari siswa serta dengan tutorial guru dan siswa dapat menyelesaikan permasalah berhitung. Dengan pendekatan matematika realistis memiliki konteks masalah adalah dasar bagi siswa untuk meningkatkan strategi informasi khusus berdasarkan pengalaman, solusi realistis untuk situasi. Ada banyak penggunaan model pembelajaran yang dieksperimenkan untuk meningkatkan hasil belajar siswa, salah satunya adalah realistic mathematics education (RME). RME adalah salah satu model pembelajaran yang menitikberatkan pada penggunaan situasi 
dunia nyata atau suatu konteks yang nyata dan pengalaman siswa sebagai titik tolak belajar matematika. Menurut Ningsih (2014) Realistic Mathematics Educations (RME) atau Pembelajaran Matematika Realistik (PMR) merupakan teori belajar mengajar dalam pendidikan matematika. Pemilihan pendekatan pembelajaran sangat berperan penting dalam peningkatan hasil belajar peserta didik karena berkaitan erat dengan ketercapaian tujuan pembelajaran atau tercapainya hasil belajar.

Menurut Wijaya (dalam Yusmanita, S., Ikhsan, M., \& Zubainur, C. M., 2018, hlm. 96) bahwa pendekatan pembelajaran matematika realistik adalah mampu membuat siswa aktif, kreatif, inovasi dan guru hanya sebagai fasilitator di dalam kelas dan guru harus mengatur kelas agar suswana kelas tetap terjaga. Menurut Ningsih (2014) Realistic Mathematics Educations (RME) atau Pembelajaran Pindidikan Matematika Realistik (PMR) merupakan materi balajar mengajary delam pendidikan matamatika. Pemilihan pendekatan pembelajaran sangat berperan dalam peningkatan hasil belajar peserta didik karena berkaitan erat dengan ketercapaian tujuan pembelajaran atau tercapainya hasil belajar. Fitria, Helena dan Syarifuddin (2014: 18) mengatakan hasil belajar dinilai sangatlah penting sebab hasil belajar ialah salah satu penentu keberhasilan peserta didik dalam bidang pembelajaran. Untuk meningkatkan proses hasil belajar yang dilakukan siswa, guru dapat mengelola proses belajar mengajar yang dapat memberikan siswa aktif dan tidak hanya diam saja atau yang hanya mendengarkan ceramah dari guru. Menurut Susanto (2016: 205) pendekatan matematika realistik merupakan salah satu pendekatan pendidikan matematika yang berorientasi pada siswa, di mana aktivitas manusia dan matematika harus dihubungkan secara nyata terhadap konteks kehidupan sehari-hari siswa secara nyata (real) pengalaman belajar. Kegiatan belajar melalui pendekatan RME harus berhubungan dengan kehidupan nyata dan menjadikan pengalaman siswa sebagai titik awal belajar.

Adapun hasil penelitian yang dilakukan oleh Rozalia Herlina (2020) yang berjudul "Pengaruh pendekatan pendidikan matematika realistik indonesia terhadap hasil belajar siswa pada materi volume bangun ruang di kelas $\mathrm{v}$ sekolah dasar negeri 01 baringin anam kecamatan baso kabupaten agam". Diperoleh thitung 4,404 sedangkan ttabel memiliki taraf yang signifikan 5\% adalah 2,00. Demikian diperoleh thitung lebih besar dari pada ttabel yaitu $4.404>2,00$ maka Ha dapat diterima dan Ho dapat ditolak. Berdasarkan hasil penelitiin dapat disimpulkan bahwa ada pengaruh Pendekatan Pendidikan Matematika Realistik Indonesia terhadap hasil belajar matematika siswa pada pembelajaran volum balok dan kubus pada siswa. Penelitian yang dilakukan oleh Ni Pt. Utami Narayani (2019) yang berjudul "Pengaruh Pendekatan Matematika Realistik Berbasis Pemecahan Permasalahan Berbantuan Media Konkret Terhadap Hasil Belajar Matematika”. Berdasarikan hasili anelisis daita dari pengujian dangan manggunakan hasil yang telah dihitung uji-t adalah thitung 9,39 sedangkan pada ttabel memiliki taraf yang signifikan 5\%. Demikian diperoleh thitung $>$ ttabel yaitu 9,39>2,05 sehingga Ho ditolak dan H1 diterima. Dapat disimpulkan bahwa terdapat pengaruh pendekatan pembelajaran. Berdasarkan hasil penelitian diatas dan berdasarkan permasalahan yang telah ditunjukkan, peneliti akan melakukan penelitian tentang "MetaAnalisis Pengaruh Pendekatan Matematika Realistik Terhadap Hasil Belajar Kognitif Siswa SD” dengan menggunakan pendekatan pembelajaran Pendekatan Matematika Realistik atau Realistic Mathematics Educations (RME) maka dapat meningkatkan hasil belajar kognitif peserta didik dan membuat peserta didik lebih aktif dalam mengikuti proses pembelajaran dikelas.

\section{METODE PENELITIAN}

Penelitian ini menggunakan desain Meta Analisis. Meta analisis adalah seperangkat Metode statistik untuk menghubungkan hasil kuantitatif dari beberapa peneliti untuk menghasilkan rangkuman secara keseluruhan atas pengetahuan empiris pada topik tertentu. Pengumpulan data dalam penelitian ini dilakukan dengan menelusuri artikel-artikel secara online dengan menggunakan Google Cendekia 
(https://scholar.google.co.id/) dan repository. Penelitian dilaksanakan dengan menggunakan 6 tahap yaitu Pertama, menentukan masalah atau topik yang akan dipelajari yaitu mengenai pengaruh pendekatan pendidikan matematika realistik (PMR) terhadap hasil belajar kognitif siswa SD. Kedua, mencari dan mengumpulkan laporan penelitian berupa jurnal nasional yang berkaitan dengan masalah atau topik yang akan diteliti dan menentukan periode temuan penelitian yang dijadikan sumber data yaitu terbit tahun 2013-2020. Ketiga, membaca laporan penelitian untuk melihat kesesuaian isi dengan masalah yang telah ditentukan, memfokuskan penelitian pada masalah berupa aspek metodologi penelitian dan mengkategorikan masingmasing penelitian atau dengan kata lain merekam informasi sebanyak-banyaknya dalam laporan penelitian. Keempat, menentukan besarnya pengaruh (Effect Size)setiap laporan penelitian dari setiap data yang diperoleh. Kelima, menganalisis laporan penelitian yang dipublikasikan berdasarkan kajian terhadap Metode dan analisis data yang digunakan, sehingga dapat ditarik kesimpulan dari penelitian meta-analisis yang dilakukan. Teknik analisis data yang digunakan dalam penelitian ini adalah teknik analisis ukuran efek atau effect size. Menghitung Effect Size menggunakan Hasil Uji-t, rumus yang digunakan untuk menguji Effect Size berdasarkan Cohen's :

$$
d=\frac{M_{\text {posttest }}-M_{\text {pretest }}}{\sqrt{\text { SDpretest }^{2}}+\text { SDposttest }^{2}}
$$

Keterangan :

$\mathrm{D}$

$M_{\text {pretest }}$

$M_{\text {posttest }} \quad$ : Mean posttest

$S D_{\text {pretest }} \quad$ : Standar deviasi pretest

$S D_{\text {posttest }} \quad$ : Standar deviasi posttes

Angka presentasi yang diperoleh selanjutnya dikelompokkan kedalam kriteria penilaian table 1 .

Tabel 1.Interpretasi Effect Size Cohen's

\begin{tabular}{|c|c|}
\hline Effect Size & Interprestasi \\
\hline $0<\mathrm{d}<0,2$ & Kecil \\
\hline $0,2<\mathrm{d} \leq 0,5$ & Sedang \\
\hline $0,5<\mathrm{d} \leq 0,8$ & Besar \\
\hline $\mathrm{d}>0,8$ & Sangat Besar \\
\hline
\end{tabular}

1) Hasil dari analisis Effect Size yang dilakukan untuk melihat besar efek Pendekatan Matematika Realistik (PMR) terhadap Hasil Belajar Kognitif Siswa Sekolah Dasar dapat diartikan bahwa semakin besar nilainya maka semakin besar efek dari Pendekatan Matematika Realistik terhadap pembelajaran Matematika Sekolah Dasar. 
1098 Meta-Analisis Pengaruh Pendekatan Pendidikan Matematika Realistik (PMR) Terhadap hasil Belajar Siswa Sekolah Dasar-Ripka Yuspin Puspitasari, Gamaliel Septian

DOI : https://doi.org/10.31004/basicedu.v5i2.878

\section{HASIL DAN PEMBAHASAN}

Hasil penelitian diperoleh 20 artikel yang terkait dengan pengaruh Pendekatan Pendidikan Matematika Realistik (PMR) terhadap hasil belajar kognitif Matematika Sekolah Dasar. Dari 20 hasil penelitian yang terdiri dari 18 jurnal ilmiah dan 2 hasil skripsi yaitu :

Pengaruh Pendekatan Pendidikan Matematika Realistik Indonesia terhadap Hasil Belajar pada Materi Volume Bangun Ruang di Kelas V Sekolah Dasar 01 Baringin Anam Kecamatan Baso Kabupaten Agam oleh Rozalia Herlina (2020), Pengaruh Pendekatan Matematika Realistik Berbasis Pemecahan Masalah Berbantuan Media Konkret terhadap Hasil Belajar Matematika oleh Ni Pt.Utami Dewi Narayani (2019), Pengaruh Penggunaan Pendekatan Matematika Realistik terhadap Hasil Belajar Matematika oleh Yuni Riawati (2016), Pengaruh Pendekatan Matematika Realistik terhadap Hasil Belajar Siswa Kelas II Pada Perkalian Bilangan Cacah di Sekolah Dasar oleh Sofie Claudia (2020), Pengaruh Pendekatan Matematika Realistik (PMR) terhadap Hasil Belajar Matematika Kelas V SDN Desa Penglatan Kecamatan Buleleng oleh Made Wirama (2014), Pengaruh Pendekatan Pendidikan Matematika Realistik Indonesia (PMRI) terhadap Hasil Belajar Matematika Siswa Kelas III SD Negeri 144 Pekanbaru oleh Helga Tri Gustina (2014), Pengaruh Pendekatan Pendidikan Matematika Realistik terhadap Hasil Belajar Matematika Siswa SD oleh Komang Ary Setiawan (2014), Pengaruh Pendekatan Realistic Mathematics Education (RME) terhadap Hasil Belajar Siswa Pada Mata Pelajaran Matematika Kelas IV SD Negeri 9 Metro Barat oleh Cici Apriyani (2017), Pengaruh Pendekatan Pendidikan Matematika Realistik Berbantu Origami terhadap Hasil Belajar Matematika Siswa Kelas V SDDI Desa Les Kecamatan Tejakul Tahun Pelajaran 2013/2014 oleh Nyoman Tri Anarta Putra (2014), Pengaruh Pendekatan Matematika Realistik Berbantu Media Sederhana terhadap Hasil Belajar Matematika oleh I Made Diana Putra (2014), Pengaruh Pendekatan Matematika Realistik Berbasis Pemecahan Masalah terhadap Hasil Belajar Matematika Siswa Kelas V SD oleh Luh Budiasih (2017), Pengaruh Pendekatan Pembelajaran Matematika Realistik terhadap Hasil Belajar Matematika ditinjau dari Tingkat Kecemasan Belajar Siswa oleh Muhlisin, N. Dantes, Sariyasa (2013), Pengaruh Pendekatan Pendidikan Matematika Realistik (PMR) terhadap Hasil Belajar Pecahan di Sekolah Dasar oleh Sri Nola Yandiana (2020), Pengaruh Penggunaan Pendekatan Matematika Realistik terhadap Hasil Belajar Matematika di Sekolah Dasar oleh Yuyun Sunarti (2017), Pengaruh Penerapan Pendekatan Matematika Realistik terhadap Hasil Belajar Siswa Kelas IV SD Pontianak Barat oleh Marsela Whenty Petryana (2017), Pengaruh Pendekatan Matematika Realistik terhadap Hasil Belajar Matematika ditinjau dari Kemampuan Numerik Siswa Kelas V SD Gugus 3 Kuta Selatan Badung oleh Ni Kadek Junairini (2014), Keefektifan Pendekatan Realistic Mathematics Education dengan Metode Drill terhadap Hasil Belajar Matematika Siswa Kelas III SD oleh Widodo Hadi Pratomo (2016), Pengaruh Pendekatan Matematika Realistik terhadap Hasil Belajar Pokok Bahasan Geometri dan Pengukuran Siswa Kelas III SDN Ambulu 01 Jember oleh Uswatun Chasanah (2016), Pengaruh Pendekatan Realistic Mathematics Education terhadap Hasil Belajar Matematika Siswa Kelas V SD Negeri 6 Metro Utara oleh Faizatur Rokhmah (2018), Pengaruh Pendekatan Realistic Mathematics Education (RME) terhadap Kemampuan Pemecahan Masalah Siswa pada Materi Operasi Hitung Campuran di Kelas IV SD IT Adzkia 1 Padang oleh Asrina Mulyati (2017).

Ke 20 artikel tersebut dipilih dikarenakan telah memenuhi kriteria yaitu adanya pembahasan tentang pendekatan Pendidikan Matematika Realistik (PMR), hasil belajar kognitif matematika di sekolah dasar danadanya data sebelum tindakan dan data sesudah tindakan. Data dari 20 artikel terdiri dari penelitian eksperimen, dari data tersebut masih sangat luas sehingga hasil penelitin tersebut dianalisis terlebih dahulu dengan mengambil intinya. Berikut adalah hasil analisis dari 20 artikel. 

Siswa Sekolah Dasar-Ripka Yuspin Puspitasari, Gamaliel Septian

DOI : https://doi.org/10.31004/basicedu.v5i2.878

Tabel 1. Peningkatan Hasil Belajar Matematika dengan Pendekatan PMR

\begin{tabular}{|llllll|}
\hline No & Peningkatan Hasil Belajar Siswa & & & \\
\cline { 2 - 6 } & Peneliti & Sebelum & Sesudah & Gain & Gain\% \\
\hline 1 & Rozalia Herlina & 55,8 & 73,5 & 17,7 & 31,72 \\
\hline 2 & Ni Pt. Utami Dewi N & 13,7 & 19,36 & 5,66 & 41,31 \\
\hline 3 & Yuni Riawati & 43,48 & 86,95 & 43,47 & 99,97 \\
\hline 4 & Sofie Claudia & 53 & 82,5 & 29,5 & 55,66 \\
\hline 5 & Made Wirama & 62,21 & 75,8 & 13,59 & 21,84 \\
\hline 6 & Helga Tri Gustina & 58,1 & 73,52 & 15,42 & 30,17 \\
\hline 7 & Komang Ary Setiawan & 41,7 & 53 & 11,3 & 27,09 \\
\hline 8 & Cici Apriyani & 42,86 & 57,14 & 14,28 & 33,31 \\
\hline 9 & Nyoman Tri Anarta P & 14,47 & 17,24 & 2,77 & 19,14 \\
\hline 10 & I Made Diana Putra & 60,22 & 71,25 & 11,03 & 18,31 \\
\hline 11 & Luh Budiasih & 14,31 & 22,91 & 8,6 & 60,09 \\
\hline 12 & Muhlisin, N. Dantes & 24,93 & 28,7 & 3,77 & 15,12 \\
\hline 13 & Sri Nola Yandiana & 75,31 & 85,31 & 10 & 13,27 \\
\hline 14 & Yuyun Sunarti & 53,8 & 75,43 & 21,63 & 40,20 \\
\hline 15 & Whenty Petryana & 65,71 & 79,73 & 14,02 & 21,33 \\
\hline 16 & Ni Kadek Juniarini & 21 & 24,7 & 3,7 & 17,61 \\
\hline 17 & Widodo Hadi Pratomo & 73,72 & 84,22 & 10,5 & 14,24 \\
\hline 18 & Uswatun Chasanah & 1,64 & 3,77 & 2,13 & 13,06 \\
\hline 19 & Faizatur Rokhmah & 52,22 & 62,31 & 10,09 & 19,32 \\
\hline 20 & Asrina Mulyati & 64,82 & 73,92 & 9,1 & 14,03 \\
\hline Mean & 44,65 & 57,56 & 12,91 & 30,34 \\
\hline & & & & & \\
\hline
\end{tabular}

Berdasarkan hasil analisis dari Tabel 1 tersebut menunjukkan bahwa Pendekatan Pendidikan Matematika Realistik (PMR) dapat meningkatkan hasil belajar siswa mulai yang terendah 13,06\% sampai yang tertinggi $99,97 \%$ dengan rata-rata peningkatan sebesar 30,34\%. Hasil belajar rata-rata sebelum dan sesudah menggunakan Pendekatan Pendidikan Matematika Realistik (PMR) terjadi peningkatan yang cukup signifikan yaitu sebesar 30,34\%. Berikut hasil Output Paired-Sample T-Test yaitu : 

Siswa Sekolah Dasar-Ripka Yuspin Puspitasari, Gamaliel Septian

DOI : https://doi.org/10.31004/basicedu.v5i2.878

Tabel 2. Statistik Sampel Berpasangan

\begin{tabular}{|llr|r|r|r|}
\hline \multicolumn{6}{|c|}{ Paired Samples Statistics } \\
\\
\hline Pair 1 & Sean & N & Std. Deviation & Std. Error Mean \\
\cline { 2 - 7 } & Sesudah & 44.6490 & 20 & 22.12771 & 4.94791 \\
\hline
\end{tabular}

Tabel 3. Kolerasi Sampel Berpasangan

\begin{tabular}{|lllll|l|}
\hline \multicolumn{7}{|c|}{ Paired Samples Correlations } & & \\
\hline & & $N$ & Correlation & Sig. & \\
\hline Pair 1 & sebelum \& sesudah & & 20 & .943 & .000 \\
\hline
\end{tabular}

Tabel 4. Uji Sampel Berpasangan

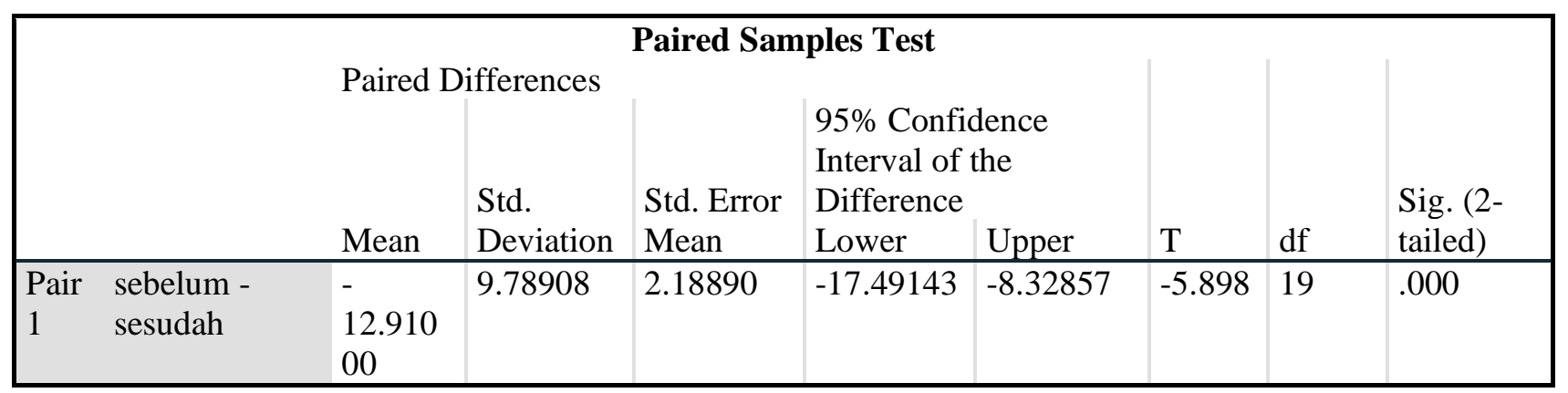

Berdasarkan hasil Output Paired-Sampel T-Tes pada table 2 menunjukkan bahwa pembelajaran dengan menggunakan Pendekatan Matematika Realistik (PMR) mampu meningkatkan hasil belajar siswa dari nilai rata-rata 44,6490 menjadi 57,5590. Hasil penelitian ini sejalan dengan penelitian yang dilakukan oleh Yuyun Sunarti pada tahun 2017 yang berjudul "Pengaruh Penggunaan Pendekatan Matematika Realistik terhadap Hasil Belajar Matematika di Sekolah Dasar". Hasil penelitian menunjukkan nilai rata-rata pretest 53,80 dan rata-rata nilai posttest 75,43 . Berdasarkan data tersebut dapat diliat rata-rata mengalami peningkatan. Penelitian lain yang sejalan adalah penelitian yang dilakukan oleh Helga Tri Gustina pada tahun 2019 yang berjudul "Pengaruh Pendekatan Pendidikan Matematika Realistik Indonesia (PMRI) terhadap Hasil Belajar Matematika Siswa Kelas III SD Negeri 144 Pekanbaru”. Hasil penelitian menunjukkan nilai rata-rata pretest 58,10 sedangkan rata-rata posttest 73,50 . Berdasarkan data tersebut dapat dilihat rata-rata mengalami peningkatan.

Pada table 3 dapat dilihat bahwa nilai Sig yaitu $0,000<0,05$. Sehingga dapat disimpulkan bahwa terdapat perbedaan rata-rata antara hasil belajar sebelum dan sesudah yang artinya terdapat pengaruh penggunaan pendekatan pembelajaran pendidikan matematika realistik dalam meningkatkan hasil belajar kognitif siswa. Kemudian pada table 4 menunjukkan bahwa nilai $\mathrm{t}$ hitung $=5,898>\mathrm{t}$ table $=2,093$, maka Ho ditolak. Sehingga dapat disimpulkan bahwa terdapat perbedan signifikan antara rata-rata awal dan rata-rata akhir tentang pengaruh pendekatan pendidikan matematika realistik (PMR) terhadap hasil belajar kognitif siswa. Hal ini sejalan dengan penelitian yang dilakukan Ni Pt. Utami Dewi pada tahun 2019 yang berjudul "Pengaruh Pendekatan Matematika Realistik Berbasis Pemecahan Masalah Berbantuan Media Konkret Terhadap Hasil Belajar Matematika". Hasil penelitian menunjukkan bahwa hasil pengujian tes siswa yaitu $t_{\text {hitung }}>t_{\text {tabel }}$ atau 9,39 $>2,05$ jadi dapat disimpulkan bahwa $H_{O}$ ditolak yang berarti bahwa terdapat pengaruh pendekatan pendidikan matematika realistik terhadap hasil belajar matematika siswa. Penelitian lain 
yang sejalan adalah penelitian yang dilakukan oleh Sri Nola Yandiana pada tahun 2020 yang berjudul "Pengaruh Pendekatan Pendidikan Matematika Realistik (PMR) Terhadap Hasil Belajar Pecahan Di Sekolah Dasar". Hasil penelitian ini menunjukkan $t_{\text {hitung }}>t_{\text {tabel }}$ atau 2,853>2,042 sehingga $H_{O}$ ditolak dan $H_{a}$ diterima jadi pendekatan pendidikan matematika realistik berpengaruh terhadap hasil belajar siswa.

Berdasarkan hasil nilai rata-rata dan nilai signifikan penelitian ini menunjukkan bahwa pendekatan pendidikan matematika realistik berpengaruh dalam meningkatkan hasil belajar kognitif siswa. Hal ini sejalan dengan penelitian yang dilakukan Asrina Mulyati (2017) bahwa dengan menggunakan pembelajaran pendidikan matematika realistik (PMR) dapat meningkatkan kemampuan pemecahan masalah siswa dari pada menggunakan pembelajaran konvensional. Penelitian yang dilakukan oleh Ni Kadek Juniarini (2014) Hasil belajar menggunakan pendekatan pendidikan matematika realistik lebih tinggi daripada pembelajaran yang menggunakan metode konvensional. Penelitian yang dilakukan oleh Whenty Petryana (2017) bahwa hasil belajar pada materi menetukan KPK dan FPB dengan menerapkan strategi ekspositori lebih rendah daripada hasil belajar yang menerapkan pendekatan pendidikan matematika realistik. Berdasarkan perhitungan effect size memperoleh hasil yaitu sebesar 0,51 dan jika dilihat pada table 1 mengenai interprestasi effect size termasuk dalam kategori besar.

Penelitian meta-analisis ini secara keseluruhan memberikan hasil effect size yang tergolong pada kriteria besar, namun memiliki keterbatasan selama dilakukannya proses penelitian. Dengan demikian, berikut ini merupakan keterbatasan-keterbatasan yang dialami oleh peneliti dalam melakukan meta-analisis. Penelitian-penelitian yang diambil untuk dianalisis sebagian besar adalah Eksperimen dimana jenis penelitian ini tidak melibatkan peneliti secara langsung di lapangan sehingga tidak dapat mengontrol semua variabel asing (ekstraneous) dengan kemungkinan terkena unsur lain dari variabel asing dapat terjadi. Sehingga hasilhasil penelitian yang dilaporkan, dianalisis dan ditafsirkan harus secara hati-hati. Sampel penelitian terdahulu yaitu artikel publikasi ilmiah pendekatan pembelajaran pendidikan matematika realistik memiliki keterbatasan dalam kelengkapan data statistk seperti hasil uji maupun metodologi seperti desain yang digunakan, sample size, lama perlakuan, materi yang diajarkan dan lainnya yang dibutuhkan oleh peneliti guna memudahkan dalam proses meta-analisis, sehingga variabel yang dapat dianalisis pun menjadi terbatas dan sedikit. Penelitian meta-analisis ini mengungkapkan dan melaporkan bahwa penerapan pendekatan pembelajaran pendidikan matematika realistik ternyata dapat meningkatkan dan memberikan kontribusi hasil belajar siswa SD.

\section{KESIMPULAN}

Berdasarkan hasil analisis dapat disimpulkan dari penelitian ini hendaknya dapat menjadikan pendekatan Pendidikan Matematika Realistik (PMR) sebagai pendekatan pembelajaran yang dapat menumbuhkan kreatifitas, motivasi yang menyenangkan sehingga dapat meningkatkan hasil belajar kognitif. Kemudian pada guru hendaknya dapat menggunakan pendekatan Pendidikan Matematika Realistik (PMR) ini pada proses pembelajaran untuk dapat meningkatkan kualitas pembelajaran serta meningkatkan hasil belajar kognitif siswa melalui pendekatan Pendidikan Matematika Realistik (PMR). Pembelajaran pendekatan Pendidikan Matematika Realistik perlu diterapkan di sekolah, hal ini dikarenakan langkah-langkah dalam pendekatan pembelajaran matematika realistik sesuai untuk melatih kemampuan berfikir kritis siswa dan siswa dapat belajar secara aktif dalam memperoleh pengetahuan. Guru dapat menggunakan pendekatan pembelajaran matematika realistik dalam variasi pemilihan pendekatan pembelajaran untuk meningkatkan motivasi dan hasil belajar siswa kognitif. Siswa diharapkan untuk lebih meningkatkan hasil belajarnya.

Berdasarkan hasil dan pembahasan yang sudah dijabarkan, maka dapat disimpulkan bahwa pendekatan matematika realistik (PMR) lebih efektif jika dibandingkan dengan pembelajaran yang tidak menggunakan 
1102 Meta-Analisis Pengaruh Pendekatan Pendidikan Matematika Realistik (PMR) Terhadap hasil Belajar Siswa Sekolah Dasar-Ripka Yuspin Puspitasari, Gamaliel Septian

DOI : https://doi.org/10.31004/basicedu.v5i2.878

pendekatan pembelajaran terhadap hasil belajar kognitif siswa. Dapat dilihat dari Uji-T nilai rata-rata skor sebelum pembelajaran dengan menggunakan pendekatan matematika realistik (PMR) sebesar 57,5590 lebih tinggi dibandingkan dengan pembelajaran yang tidak menggunakan pendekatan matematika realistik 44,6490. Dapat disimpulkan bahwa terdapat perbedaan dari pembelajaran yang menggunakan pendekatan matematika realistik dengan pembelajaran yang tidak menggunakan pendekatan matematika realistik. Berdasarkan perhitungan Effect Size yang diketahui bahwa Standar Deviation sebesar 0,51. Hal ini menunjukkan bahwa pendekatan matematika realistik (PMR) memberika pengaruh tergolong besar terhadap hasil belajar kognitif siswa Sekolah Dasar.

\section{DAFTAR PUSTAKA}

Ary Setiawan, Km, Ndara Tanggu Renda, and Ni Wyn Rati. 2014. Pengaruh pendekatan pendidikan matematika realistik terhadap hasil belajar matematika siswa SD. Jurusan $\quad P G S D, \quad$ Vol $2 . \quad[$ Online] https://ejournal.undiksha.ac.id/index.php/JJPGSD/article/view/2533

Budiasih, Luh, A. A. Gede Agung, Md Citra Wibawa. 2017. Pengaruh pendekatan matematika realistik berbasis pemecahan masalah terhadap hasil belajar matematika siswa kelas V SD. Jurusan PGSD, Vol 5. [Online] https://ejournal.undiksha.ac.id/index.php/JJPGSD/article/view/10923

Claudia, Sofie, Yusuf Suryana, and Oyon Haki Pranata. 2020. Pengaruh Pendekatan Matematika Realistik Terhadap Hasil Belajar Siswa Kelas II Pada Perkalian Bilangan Cacah di Sekolah Dasar. PEDADIDAKTIKA: JURNAL ILMIAH PENDIDIKAN GURU SEKOLAH DASAR. Vol 7. [Online] https://ejournal.upi.edu/index.php/pedadidaktika/article/view/26382

Devy Indriyasari. 2017. Peningkatan Hasil Belajar Matematika Dengan Pendekatan RME Pada Siswa Kelas 5 Sekolah Dasar Negeri Sumberejo 01 Tahun Pelajaran 2017/2018. Jurnal Pendidikan. [Online] https://jurnal.fkip.uns.ac.id/index.php/jpi/article/view/10784

Gustina, Helga Tri, Syahrilfuddin, and Noviana. 2019. Pengaruh pendekatan pendidikan matematika realistik indonesia (PMRI) terhadap hasil belajar matematika siswa kelas III SD Negeri 144 Pekanbaru. Jurnal Penelitian Ilmu Pendidikan 2(1):30. doi: 10.31258/jta.v2i1.30-39.[Online] https://jta.ejournal.unri.ac.id/index.php/JTA/article/view/7028

Hapsari, Anindyakusuma, Ritohardoyo. 2013. Jurnal Informasi Kimia Dan Pemodelan. Journal of Chemical Information and Modeling 53(9):1689-99.

Kadek Juniarini, Ni Nyoman Dantes, and Gede Rasben Dantes. 2014. Pengaruh pendekatan matematika realistik terhadap hasil belajar matematika ditinjau dari kemampuan numerik siswa kelas V SD Gugus Kuta Selatan, Badung. Jurnal Pendidikan.Vol.4.[Online] https://media.neliti.com/media/publications/122879-ID-pengaruh-pendekatan-realistik-matematika.pdf

Kartika Sari, Dyah. 2017. Peningkatan hasil belajar ips menggunakan model kooperatif tipe numbered heads together (nht) pada siswa kelas 6 sekolah dasar. Jurnal Penelitian Pendidikan 34(1):9-14. doi: 10.15294/jpp.v34i1.10902.[Online] https://journal.unnes.ac.id/nju/index.php/JPP/article/view/10902

Muh. Farid Wajdih. 2020. Meta-analisis pembelajaran pendidikan matematika realistis (rme) terhadap hasil belajar matematika. Journal of Islamic Education. Retrieved January 19, 2021. [Online] http://103.55.216.56/index.php/alasma/article/view/17340

Muhlisin, N, and Sariyasa Dantes. 2013. Pengaruh Pendekatan Pembelajaran Matematika Realistik Terhadap Hasil Belajar Matematika Ditinjau Dari Tingkat Kecemasan Belajar Siswa. Ganesha University of Education, Vol. 3. [Online] https://www.neliti.com/publications/121201/pengaruh-pendekatanpembelajaran-matematika-realistik-terhadap-hasil-belajar-mat

Narayani, Ni Pt. Utami Dewi. 2019a. Pengaruh Pendekatan Matematika Realistik Berbasis Pemecahan Masalah Berbantuan Media Konkret Terhadap Hasil Belajar Matematika. Jurnal Ilmiah Sekolah Dasar3(2):220.doi:10.23887/jisd.v3i2.17775.[Online] 
1103 Meta-Analisis Pengaruh Pendekatan Pendidikan Matematika Realistik (PMR) Terhadap hasil Belajar Siswa Sekolah Dasar-Ripka Yuspin Puspitasari, Gamaliel Septian

DOI : https://doi.org/10.31004/basicedu.v5i2.878

https://ejournal.undiksha.ac.id/index.php/JISD/article/view/17775

Prakoso, Galuh Adi. 2015. Keefektifan model pembelajaran pair check dan numbered-heads together (nht) ditinjau dari hasil belajar dalam pembelajaran ips kelas 4 sdn gugus mahesa jenar ambarawa. Scholaria : Jurnal Pendidikan dan Kebudayaan 5(3):100. doi: 10.24246/j.scholaria.2015.v5.i3.p100-119.[Online] https://ejournal.uksw.edu/scholaria/article/view/32

Pratomo, Widodo Hadi. 2016. Keefektifan pendekatan realistic mathematics education dengan metode dril terhadap hasil belajar matematika siswa kelas iii sdn peterongan semarang. Jurnal Pendidikan,3(2):142.doi:10.23917/ppd.v3i2.3953.[Online] http://journals.ums.ac.id/index.php/ppd/article/view/3953

Putra, I. Md Diana, Wyn Darsana, I. B. Surya Manuaba. 2014. Pengaruh pendekatan matematika realistik berbantuan media sederhana terhadap hasil belajar matematika.Jurnal PGSD,Vol.2.[Online] https://ejournal.undiksha.ac.id/index.php/jijpgsd/article/view/2241

Rozalia Herlina. 2020. Pengaruh pendekatan pendidikan matematika realistik indonesia terhadap hasil belajar siswa pada materi volume bangun ruang di kelas $\mathrm{v}$ sekolah dasar negeri 01 baringin anam kecamatan baso kabupaten agam. Universitas islam negeri sultan syarif kasim riau pekanbaru. [Online] http://repository.uin-suska.ac.id/25428/

Sri Nola Yandiana. 2020. Pengaruh Pendekatan Pendidikan Matematika Realistik Indonesia (PMRI) Terhadap Hasil Belajar Siswa. Jurnal Pendidikan, 4(3). doi: 10.26740/mathedunesa.v9n1.p55-60. [Online] https://jptam.org/index.php/jptam/article/download/796/713

Sugiyono. Pendekatan Penelitian. Jurnal Pendidikan

Sunarti, Yuyun, K. Y. Margiati, and Utami. 2017. Pengaruh Penggunaan Pendekatan Matematika Realistik Terhadap Hasil Belajar Matematika Di Sekolah Dasar. Tanjungpura University,Vol.6.[Online] https://jurnal.untan.ac.id/index.php/jpdpb/article/view/18741

Tri, Nyoman, Anarta Putra. I Made Suarjana. I Gusti, Ngurah Japa. 2014. Pengaruh pendekatan pendidikan matematika realistikberbantuan origami terhadap hasil belajar matematikasiswa kelas v sddi desa les kecamatan tejakula tahun pelajaran 2013/2014.JurnalPendidikan, Vol.2. [Online] https://ejournal.undiksha.ac.id/index.php/JJPGSD/article/view/2839

Turdjai. 2014. Pengaruh Pendekatan Pembelajaran Terhadap Hasil Belajar Mahasiswa.” Turdjai 15(2):17-29.

Whenty, Marsela, Petryana. 2017. Pengaruh penerapan pendekatan matematika realistik terhadap hasil belajar siswa kelas iv sd pontianak barat. Program, Studi Pendidikan Guru, Sekolah Dasar, Jurusan Pendidikan, Dasar Fkip, and Untan Pontianak.[Online] https://jurnal.untan.ac.id/index.php/jpdpb/article/view/18817

Wimbang Tantomo Ramajuna. 2017. Hubungan motivasi dan lingkungan keluarga dengan pengambilan keputusan memilih program studi pendidikan administrasi perkantoran. Fakultas keguruan dan ilmu $\begin{array}{lllll}\text { pendidikan universitas } & \text { sebelas } & \text { maret, } & \text { Vol } & 2(1) .\end{array}$ https://jurnal.uns.ac.id/JIKAP/article/view/19538

Wirama, Md, Kt Pudjawan, I. Kt Dibia. 2014. Pengaruh pendekatan matematika realistik (pmr) terhadap hasil belajar matematika kelas v sd $\mathrm{n}$ desa penglatan kecamatan buleleng. Jurnal PGSD, Vol. 2. [Online] https://ejournal.undiksha.ac.id/index.php/JJPGSD/article/view/2436)

Yuni Riawati. 2016. Pengaruh penggunaan pendekatan pendidikan matematika realistik terhadap hasil belajar matematika. Jurnal Pendidikan, 5(9):865-73.

Marselina, Km. Tria and MG. Rini Kristiantari. 2019. Pengaruh Pendekatan Pembelajaran Matematika Realistik Berbasis Portofolio terhadap Kompetensi Pengetahuan Matematika. Journal of Education Technology 3(2):81. doi: 10.23887/jet.v3i2.21708. [Online] https://ejournal.undiksha.ac.id/index.php/JET/article/view/21708 